\title{
Proteolysis and volatile components of reduced-fat cheeses made from ultrafiltered milk and different starters supplemented with lactobacilli and Lac-Prt' $^{-}$lactococci
}

\author{
$\mathrm{J} \mathrm{Rodríguez}^{1}$, T Requena ${ }^{1 *}, \mathrm{E}_{\text {Valero }}{ }^{2}$, I Martínez-Castro ${ }^{2}$, \\ R López-Fandiño ${ }^{3}$, M Juárez ${ }^{1}$ \\ I Instituto del Frio (CSIC), Ciudad Universitaria, 28040 Madrid; \\ ${ }^{2}$ Instituto de Química Orgânica General (CSIC); \\ ${ }^{3}$ Instituto de Fermentaciones Industriales (CSIC), Juan de la Cierva 3, 28006 Madrid, Spain
}

(Received 20 January 1997; accepted 12 May 1997)

\begin{abstract}
Summary - Proteolysis and volatile components of semi-hard cheeses manufactured from a mixture of cow's, ewe's and goat's milk, with reduced fat content and concentrated by ultrafiltration, were followed during ripening. A starter culture (IFPL), consisting of several strains of Lactococcus, Lactobacillus and Leuconostoc, selected previously for its high proteolytic activity, and the same starter with the addition of a concentrate of Lactococcus lactis subsp lactis T1, lacking the ability to utilize lactose and casein $\left(\mathrm{Lac}^{-} \mathrm{Prt}^{-}\right)$, were tested with the aim of accelerating cheese ripening as compared with a commercial starter (FD). Casein hydrolysis was not affected by the type of starter culture employed, whereas appreciable differences were found in the non-volatile water-soluble nitrogen fraction. The peptide pattern allowed a clear distinction among cheeses made with different bacterial cultures. IFPL cheeses exhibited, after 1 month of ripening, a higher content of total free amino acids than FD cheeses after 3 months of ripening. Furthermore, the addition of $L$ lactis $\mathrm{T} 1$ to the IFPL culture noticeably increased the release of total free amino acids during ripening, as well as the content of total volatile compounds.
\end{abstract}

reduced-fat cheese / proteolysis / starter / volatile component / Lac-Prt- lactococci

Résumé - Protéolyse et composés volatils de fromages à teneur réduite en matière grasse préparés avec du lait ultrafiltré et différents levains additionnés de lactobacilles et de lactocoques Lac-Prt- La protéolyse et les composés volatils ont été suivis pendant l'affinage de fromages à teneur reduite en matière grasse, préparés à partir d'un mélange de lait (vache, brebis, chèvre) ultrafiltré. Pour accélérer l'affinage, un levain (IFPL) contenant plusieurs souches de Lactococcus, Lactobacillus et Leuconostoc (préalablement sélectionnés pour leur activité protéolytique élevée), et le

* Correspondence and reprints 
même levain additionné d'une souche de Lactoccocus lactis subsp lactis T1 (Lac-Prt'), ont été comparés avec un levain commercial (FD). Le type de levain employé n'a pas montré d'effet sur l'hydrolyse de la caséine, mais semble entrainer des différences dans la fraction azotée hydrosoluble non volatile. Les profils peptidiques des fromages préparés avec les trois levains étaient différents et très caractéristiques. La teneur en acides aminés des fromages préparés avec le levain IFPL après seulement un mois d'affinage était plus élevée que celle des fromages préparés avec le levain FD après 3 mois. L'addition de la souche $L$ lactis T1 augmentait la production des acides aminés pendant l'affinage. Les fromages préparés avec cette souche avaient aussi la plus haute teneur en composés volatils (alcools, cétones, esters et dérivés soufrés).

fromage à matière grasse réduite/ protéolyse/ levain/ composé volatil/ lactocoque Lac-Prt-

\section{INTRODUCTION}

Demand for low-fat cheeses has increased during the past few years, as a consequence of the consumers' requirements for low caloric and low cholesterol foods. Unfortunately, the reduction in the fat content impairs the sensorial properties of the cheese, and therefore, different strategies have been used in order to improve texture and flavour (Drake and Swanson, 1995). The use of ultrafiltration (UF) concentrates gives higher yields and softer curds, however, there are problems to be solved arising from the slowdown of ripening and flavour development, which is probably due to increased levels of proteinase and peptidase inhibitors and the ability of whey proteins to link some aroma compounds (De Koning et al, 1981; Lelièvre and Lawrence, 1988; Bech, 1993). In addition, cheese ripening and flavour development can be accelerated by addition of extra enzymes, heat-shocked starters or modified bacteria to the cheese milk, or by the use of elevated ripening temperatures and combinations of these strategies (Coulson et al, 1992; El Soda, 1993). Bacterial enzymes can also be added by using bacteria with high autolytic properties (Crow et al, 1995).

We have developed a specific starter culture (IFPL) consisting of several strains of Lactococcus, Lactobacillus and Leuconos- toc, which has been proved to be suitable for the manufacture of semi-hard goat's milk cheese (Requena et al, 1992). A Lactococcus strain from this starter was plasmid cured in order to reduce its proteolytic activity $\left(\mathrm{Prt}^{-}\right)$and capacity to metabolize lactose $\left(\mathrm{Lac}^{-}\right)$, keeping its peptidolytic activity (Requena and McKay, 1993). This derivative lactococcal strain (T1), along with the parental strain (IFPL 359), was found to accelerate proteolysis in low-fat cheese slurries (Rodríguez et al, 1996a). Furthermore, reduced-fat semi-hard cheeses made with a mixture of cow's, ewe's and goat's milk concentrated by UF, and with the addition of IFPL starter supplemented with $\mathrm{T} 1$, reached the desired characteristics of a mature cheese in a shorter period of time, as compared with cheeses made with a commercial starter (Rodríguez et al, 1996b). Proteolysis was enhanced in the IFPL cheeses, which achieved a right balance of flavour and aroma. Because small peptides, free amino acids, free fatty acids, volatile components and their by-products are thought to contribute to cheese flavour, we have carried out a detailed study on the evolution of proteolysis, lipolysis and formation of volatile components during ripening of those experimental cheeses. In this paper these results are related to the previously published data on enhancement of flavour development. 


\section{MATERIALS AND METHODS}

\section{Cheese samples}

Cheeses were manufactured in the pilot plant of the Laboratoire de Recherches de Technologie Laitière (Inra, Rennes, France), from approximately $190 \mathrm{~kg}$ of heated $\left(92^{\circ} \mathrm{C}, 4 \mathrm{~s}\right)$ semi-skimmed ( $23 \mathrm{~g} / \mathrm{kg}$ fat) mixed milk (cow's/ewe's/goat's: $55 / 15 / 30$ ). Milk was ultrafiltered at $50^{\circ} \mathrm{C}$ to sixfold concentration as described by Goudédranche et al (1980). The concentrate $(25 \mathrm{~kg})$ was separated in three batches and the various freezedried starter cultures were added to give counts of $10^{10}$ colony forming units (cfu) $/ \mathrm{kg}$ retentate. Batch FD contained a commercial starter culture (Flora Danica MSP, Chr Hansen, Denmark), batch IFPL contained strains from the culture collection of the Instituto del Frío (Departamento de Productos Lácteos, Madrid, Spain), and batch IFPL (T1) contained the IFPL starter culture and a concentrate of L lactis subsp lactis $\mathrm{T} 1$ ( $\mathrm{Lac}^{-}$ $\mathrm{Prt}^{-}$) (which increased total counts in the retentate up to $10^{11} \mathrm{cfu} / \mathrm{kg}$ ). Cheese manufacturing, ripening conditions and sampling were described previously (Rodríguez et al, 1996b). Mean values of total solids (TS) and salt on moisture of cheeses were $41.4 \%$ and $2.1 \%$, respectively, and the average contents of fat and protein were (\%TS) 36.0 and 53.3 , respectively. The moisture in non-fat solid content of the cheeses was $68 \%$. Microbiological and physico-chemical characteristics of cheeses have been reported as well (Rodríguez et al, 1996b).

\section{Polyacrylamide gel electrophoresis of the casein fraction}

Cheese $(5 \mathrm{~g})$ was mixed with $10 \mathrm{~mL}$ deionized water and homogenized using an Ultraturrax $\left(5 \mathrm{~min}\right.$ at $40^{\circ} \mathrm{C}$ ). Whole casein was separated by precipitation with $100 \mathrm{~mL}$ acetic acid/L to $\mathrm{pH}$ 4.6. The casein precipitate was washed repeatedly with deionized water and centrifuged $(3000 \mathrm{~g}$, $20 \mathrm{~min}, 5^{\circ} \mathrm{C}$ ) after each wash, before it was freeze-dried. The lyophilized casein fractions were analyzed by means of urea-PAGE according to the method of Ramos et al (1977). Electrophoresis was carried out on slabs $0.7 \mathrm{~mm}$ thick and the bands were stained with Coomassie blue R250 (Winter et al, 1977).

\section{Peptide analysis by HPLC}

Peptide analyses were carried out as described by González de Llano et al (1995). Cheese (10 g) was mixed with $50 \mathrm{~mL}$ deionized water and homogenized using an Ultraturrax $\left(5 \mathrm{~min}\right.$ at $\left.40^{\circ} \mathrm{C}\right)$. The homogenate was then held for $10 \mathrm{~min}$ at $40^{\circ} \mathrm{C}$ and filtered through glass wool. Afterwards, it was filtered through a Durapore 0.45 $\mu \mathrm{m}$ filter (Millipore Corp, Bedford, USA) and $50 \mu \mathrm{L}$ was injected on to the column.

A Beckman System Gold HPLC was used together with a System Gold Software data acquisition system (Beckman Instruments Inc, San Ramon, USA). Separations were performed on a C18 Nucleosil $5 \mu \mathrm{m}, 300 \AA$ Å column $(250 \times 4.6$ $\mathrm{mm}$ ) (Macherey Nagel Düren, Düren, Germany) at $40^{\circ} \mathrm{C}$. Solvent A was $1 \mathrm{~mL}$ trifluoroacetic acid (TFA; Merck, Darmstadt, Germany)/L Milli$\mathrm{Q}$ water (Millipore) and solvent B was $1 \mathrm{~mL}$ TFA/L in acetonitrile (HPLC grade from Scharlau, Barcelona, Spain) and water $(60: 40 \mathrm{v} / \mathrm{v})$. Separations were performed following the method described by González de Llano et al (1995). A flow rate of $1 \mathrm{~mL} / \mathrm{min}$ was employed with detection at $220 \mathrm{~nm}$.

The aromatic amino acids tyrosine, phenylalanine and tryptophan, as well as whey proteins $(\alpha$-lactalbumin and B-lactoglobulin A and B) (Sigma, St Louis, USA) were run on the HPLC to identify their retention times.

\section{Amino acid content}

Free amino acids were extracted from cheese according to the method of Resmini et al (1993). Samples (1.5 g) of cheese were blended with $40 \mathrm{~mL}$ citrate $/ \mathrm{HCl}$ buffer, $\mathrm{pH} 2.2$ (composed of $19.61 \mathrm{~g}$ tri-sodium citrate dihydrate, $0.1 \mathrm{~g}$ sodium azide and $200 \mathrm{mg}$ EDTA in $1 \mathrm{~L}$ deionized water) and filtered through a Whatman no 40 filter paper. The filtrate was mixed with a sulphosalicylic acid solution in citrate buffer (final concentration of $30 \mathrm{~g} / \mathrm{L}$ ), filtered, heated at $84{ }^{\circ} \mathrm{C}$ for $10 \mathrm{~min}$, to denature whey proteins, centrifuged $(5000 \mathrm{rpm}, 10 \mathrm{~min})$ and filtered $(0.2 \mu \mathrm{m})$. The filtrate $(50 \mu \mathrm{L})$ was analyzed using a Biochron 20 amino acid analyzer (Pharmacia LKB, Uppsala, Sweden). 


\section{Analysis of volatile components}

Cheese $(1 \mathrm{~g})$ was suspended in $3 \mathrm{~mL}$ of Milli-Q water (previously boiled for $20 \mathrm{~min}$ ) using an Ultraturrax, and the $\mathrm{pH}$ adjusted to 7.5 by addition of $\mathrm{NaOH} 0.1 \mathrm{~N}$ as recommended by Bosset and Gauch (1993). 2-Hexanone was added as internal standard. Analyses were carried out in triplicate. Volatile compounds from cheese were isolated with a HP-7695 Purge \& Trap concentrator coupled to a HP 6890 gas chromatograph (both from Hewlett-Packard, Avondale, USA) following the procedure described by Bosset and Gauch (1993) with minor modifications. Chromatographic column was from fused silica $(50 \mathrm{~m} \times 0.22 \mathrm{~mm} \times 0.25 \mu \mathrm{m})$ coated with BP-20 (SGE, Ringwood, Australia). Nitrogen was used as carrier gas with a flow rate of $1 \mathrm{~mL} / \mathrm{min}$ in split mode (split ratio 1:20). Column temperature was held at $35^{\circ} \mathrm{C}$ for $15 \mathrm{~min}$ and then programmed at $5{ }^{\circ} \mathrm{C} / \mathrm{min}$ up to $180{ }^{\circ} \mathrm{C}$ for $5 \mathrm{~min}$. The system efficiency (concentrator + column) was measured in isothermal conditions and considered satisfactory $(\mathrm{H}=0.39 \mathrm{~mm}$ at $\mathrm{k}=2.4)$. Peak areas were calculated using the HP-ChemStation software.

\section{GC-MS analysis}

Volatiles were isolated following a dynamic headspace procedure based in stripping with nitrogen and trapping on Tenax, followed by thermal desorption, detailed elsewhere (Valero et al, 1997). GC-MS analysis was carried out using a capillary column identical to that described above with helium as carrier gas and a GC- 8000 gas chromatograph with a MD-800 quadrupole mass detector working in EI mode at $70 \mathrm{eV}$ (Fisons Instruments, Milan, Italy)

\section{Free fatty acid (FFA) analysis}

Lipid extraction was carried out on an acidified cheese slurry using ethyl ether (Martín-Hernández et al, 1988). Methylation of the FFA fraction was performed with $20 \%$ of tetramethylammonium hydroxide in methanol (MartínezCastro et al, 1986). FFA were analyzed on a fused silica capillary column $(50 \mathrm{~m} \times 0.22 \mathrm{~mm} \times 0.22 \mu \mathrm{m})$ coated with Silar 5CP (Chrompack, Middelburg, the Netherlands) using a Perkin-Elmer 8420 apparatus (Perkin-Elmer, Beaconsfield, UK) equipped with a PTV injector, with helium as carrier gas (split ratio 1:20). Oven temperature was held at $70^{\circ} \mathrm{C}$ for $3 \mathrm{~min}$, raised up to 190 at $13^{\circ} \mathrm{C} / \mathrm{min}$, with a final hold of $25 \mathrm{~min}$. Other details were as described by Juárez et al (1992).

\section{RESULTS AND DISCUSSION}

\section{Casein degradation}

No differences were found among the three batches with respect to the primary casein breakdown. In all cases, $\alpha_{\mathrm{s}}$-caseins to the three species were hydrolysed faster than B-caseins. After 15 days of ripening, the typical breakdown pattern consisted of degradation products of high electrophoretic mobility, probably derived from the action of rennet on $\alpha_{s}$-caseins, together with bands of low mobility and $\gamma$-caseins resulting from the hydrolysis of $B$-caseins. This did not change significantly during the ripening period studied. Figure 1 shows, as an example, the electrophoretic pattern of caseins from cheeses made with IFPL starter with the addition of L lactis subsp lactis $\mathrm{T} 1$ during ripening.

\section{Peptides present in the water soluble fraction}

Figure 2 shows the reverse phase-HPLC separation of peptides in the water soluble fractions of the cheeses at 90 days of ripening. In agreement with the increased retention of whey proteins in the curd of the UF cheeses, a considerable amount of $\alpha$-lactalbumin and B-lactoglobulin, as well as some large water-soluble degradation products, were eluted after $80 \mathrm{~min}$ (results not shown). The RP-HPLC profiles allowed a clear distinction between batch FD, made with the commercial starter, and the batches made with the IFPL starter. This indicates that unlike the primary proteolysis, peptidolysis in the cheeses was greatly influenced by 


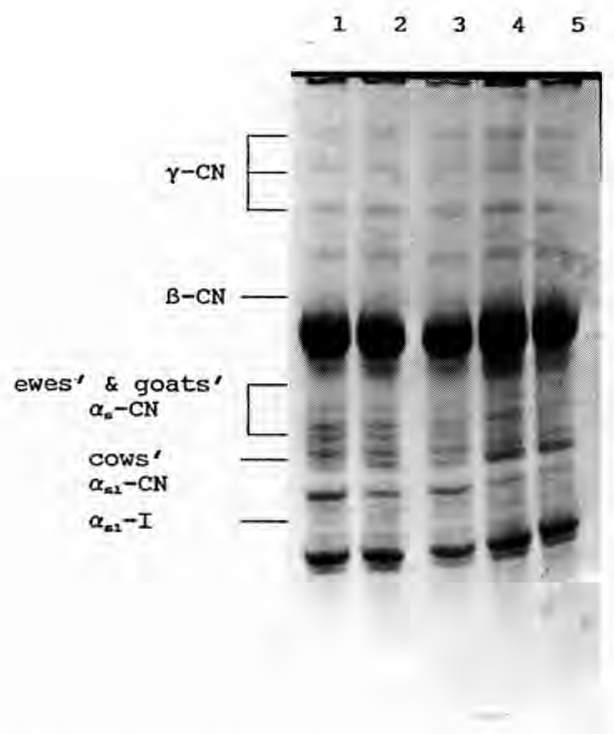

Fig 1. Urea-PAGE pattern of the casein fraction of the cheeses made with the mixed starter of local strains (IFPL) supplemented with Lactococcus lactis subsp lactis T1, Lac- Prt', after 15 $(1), 30(2), 45(3), 60$ (4) and 90 (5) days of ripening.

Distribution (urée-PAGE) de la fraction caséinique des fromages préparés avec le levain IFPL contenant plusieurs souches, additionné d'une souche de Lactococcus lactis subsp lactis $T I$ Lac ${ }^{-}$Prt, après 15 (1), 30 (2), 45 (3), 60 (4) et 90 (5) jours d'affinage.

the type of starter used. These differences could be mainly due to strain variations in aminopeptidase activities (El Abboudi et al, 1991; Requena et al, 1993; Parra et al, 1996) and to differences in sensitivity for lysis (Chapot-Chartier et al, 1994; Wilkinson et al, 1994). Aminopeptidase $\mathrm{N}$ activity of $L$ lactis has been shown to play a role in the hydrolysis of low molecular mass bitter peptides that are formed during the breakdown of casein by rennet or starter proteinase (Baankreis, 1992; Tan et al, 1993). No substantial differences were found between the peptide patterns of the two batches made with the IFPL starter throughout the ripening period.
It is assumed that large or hydrophobic peptides should exhibit higher retention on a reverse phase column, and it has been suggested that peptides eluting after Trp (retention time: $35 \mathrm{~min}$ ) constitute the hydrophobic peptide portion (Lau et al, 1991; González de Llano et al, 1995). The presence of hydrophobic peptides in cheese has been associated with bitter taste, and their degradation upon ripening to yield hydrophilic peptides is thought to contribute to cheese flavour (Cliffe et al, 1989; Engels and Visser, 1994). The total amount of peptide material was higher in batch FD than in the other two batches, although the IFPL cheeses contained more peptides in the fraction with the latest retention time. Nevertheless, it should be noticed that no bitter flavour was detected by the taste panel in the cheeses made with the IFPL starter (Rodríguez et al, 1996b).

\section{Amino acid content}

Table I shows the results of free amino acid content in UF-cheeses made with either FD or IFPL starters during ripening. After 1 month of ripening, IFPL cheeses contained higher content of free amino acids than FD cheeses after 3 months of ripening. The total level of free amino acids in FD cheese at this time was $56 \%$ of that found in IFPL cheese, and only $41 \%$ of that found in IFPL (T1). Strains of the IFPL starter had been selected on the basis of their high proteolytic activities (Requena et al, 1993) and could be responsible for the acceleration of the free amino acid release in UF-cheeses and for the lower amount of peptide material (fig 2). Increase in total amino acids when strains of mesophilic lactobacilli are included as cheese starter adjuncts has been reported (Lemieux et al, 1989; Lee et al, 1990). The mutant strain $\mathrm{T} 1$ ( $\left.\mathrm{Lac}^{-} \mathrm{Prt}^{-}\right)$, in addition to retaining all peptidase activity from the parental strain L lactis subsp lactis IFPL 359 (Requena and McKay, 1993), has 

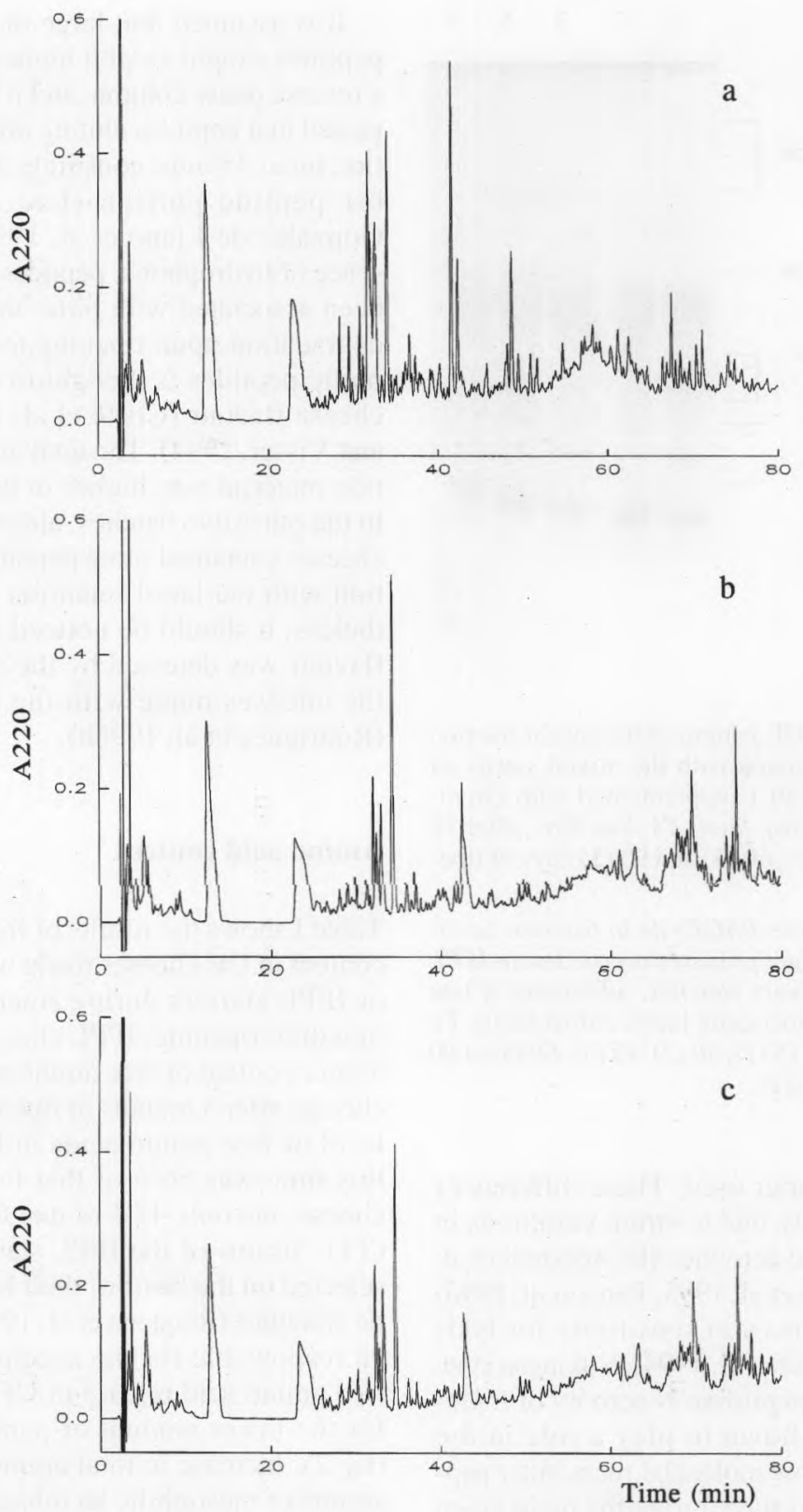

Fig 2. HPLC profiles of the water soluble nitrogen fraction of cheeses made with the commercial starter (FD) (a), the mixed starter of local strains (IFPL) (b), and the IFPL starter supplemented with Lactococcus lactis subsp lactis $\mathrm{T} 1, \mathrm{Lac}^{-} \mathrm{Prt}^{-}(\mathbf{c})$, after 90 days of ripening.

Profils HPLC de la fraction azotée soluble dans l'eau des fromages préparés avec du levain commercial (FD), le levain IFPL contenant plusieurs souches, et le même additionné d'une souche de Lactococcus lactis subsp lactis $T 1$ ( Lac $\left.^{-} \mathrm{Prt}^{-}\right)$, après 90 jours d'affinage. 
Table I. Free amino acid content ( $\mu \mathrm{mol} / \mathrm{g}$ ) of cheeses elaborated with commercial starter (FD), the mixed starter of local strains (IFPL) and the IFPL starter supplemented with Lactococcus lactis subsp lactis $\mathrm{T} 1$ ( $\left.\mathrm{Lac}^{-} \mathrm{Prt}^{-}\right)$during ripening $(15,30,45,60$ and 90 days).

Acides aminés libres ( $\mu$ mol/g) de fromages préparés avec du levain commercial (FD), le levain IFPL contenant plusieurs souches, et le même additionné d'une souche de Lactococcus lactis subsp lactis $T 1$ (Lac ${ }^{-}$Prt $\left.^{-}\right)$, pendant l'affinage (15, 30, 45, 60 et 90 jours).

\begin{tabular}{|c|c|c|c|c|c|c|c|c|c|c|c|c|c|c|c|}
\hline \multirow[b]{2}{*}{ Amino acids } & \multicolumn{5}{|c|}{ FD starter } & \multicolumn{5}{|c|}{ IFPL starter } & \multicolumn{4}{|c|}{ IFPL (T1) starter } & \multirow[b]{2}{*}{$90 \mathrm{~d}$} \\
\hline & $15 \mathrm{~d}$ & $30 \mathrm{~d}$ & $45 \mathrm{~d}$ & $60 \mathrm{~d}$ & $90 \mathrm{~d}$ & $15 \mathrm{~d}$ & $30 \mathrm{~d}$ & $45 \mathrm{~d}$ & $60 \mathrm{~d}$ & $90 \mathrm{~d}$ & $15 \mathrm{~d}$ & $30 \mathrm{~d}$ & $45 d$ & $60 d$ & \\
\hline Alanine & 1.40 & 1.24 & 2.69 & 3.13 & 4.99 & 2.12 & 2.92 & 2.79 & 5.57 & 6.72 & 2.40 & 2.88 & 3.89 & 4.92 & 9.20 \\
\hline Arginine & 0.11 & 0.11 & 0.32 & 0.21 & 0.39 & 0.24 & 0.16 & 0.17 & 0.15 & 0.13 & 0.19 & 0.08 & 0.12 & 0.16 & 0.08 \\
\hline Aspartic acid & 0.52 & 0.51 & 0.96 & 0.89 & 1.27 & 1.27 & 1.48 & 1.80 & 2.85 & 2.93 & 1.27 & 1.56 & 2.16 & 2.36 & 3.72 \\
\hline Glutamic acid & 2.96 & 2.57 & 5.96 & 6.03 & 9.76 & 7.47 & 10.84 & 10.56 & 18.28 & 18.20 & 8.77 & 10.04 & 13.13 & 16.33 & 25.67 \\
\hline Glycine & 0.51 & 0.53 & 1.13 & 0.99 & 1.57 & 1.35 & 2.03 & 1.89 & 3.48 & 3.64 & 1.68 & 1.87 & 2.35 & 3.01 & 4.95 \\
\hline Histidine & 0.20 & 0.13 & 0.45 & 0.39 & 0.64 & 1.29 & 1.69 & 1.59 & 2.00 & 2.84 & 1.47 & 1.59 & 1.84 & 2.39 & 3.72 \\
\hline Isoleucine & 0.65 & 0.61 & 1.56 & 1.40 & 2.81 & 1.40 & 2.07 & 2.11 & 3.57 & 4.77 & 1.59 & 2.07 & 2.72 & 3.55 & 6.48 \\
\hline Leucine & 2.24 & 2.00 & 4.32 & 4.89 & 8.55 & 7.19 & 11.12 & 10.28 & 15.85 & 16.13 & 8.83 & 9.76 & 11.99 & 14.91 & 20.96 \\
\hline Lysine & 0.81 & 0.69 & 1.39 & 1.29 & 2.49 & 3.07 & 4.41 & 4.16 & 7.21 & 8.09 & 3.65 & 4.05 & 5.08 & 6.92 & 11.45 \\
\hline Methionine & 0.67 & 0.65 & 1.29 & 1.17 & 1.83 & 1.09 & 1.44 & 1.35 & 2.01 & 2.31 & 1.25 & 1.47 & 1.72 & 2.09 & 3.04 \\
\hline Phenylalanine & 1.93 & 1.11 & 3.20 & 3.20 & 5.05 & 3.19 & 4.81 & 4.51 & 5.59 & 5.52 & 3.85 & 4.09 & 4.81 & 5.89 & 7.41 \\
\hline Proline & 0.96 & 0.77 & 1.45 & 1.69 & 2.77 & 4.56 & 6.19 & 6.80 & 11.93 & 11.08 & 4.84 & 5.32 & 8.13 & 9.84 & 16.33 \\
\hline Serine & 1.81 & 1.63 & 4.05 & 3.69 & 6.21 & 3.87 & 6.13 & 5.57 & 9.35 & 9.20 & 4.92 & 5.39 & 7.01 & 8.88 & 13.09 \\
\hline Threonine & 0.79 & 0.73 & 1.85 & 1.81 & 3.27 & 1.56 & 2.04 & 2.13 & 4.00 & 4.96 & 1.68 & 2.08 & 2.88 & 3.36 & 6.89 \\
\hline Tyrosine & 0.64 & 0.73 & 2.21 & 1.87 & 3.21 & 0.99 & 1.75 & 1.59 & 2.15 & 2.47 & 1.29 & 1.37 & 1.67 & 2.47 & 3.36 \\
\hline Valine & 2.80 & 2.48 & 4.28 & 5.35 & 7.89 & 4.63 & 7.01 & 6.52 & 11.11 & 12.55 & 5.60 & 6.37 & 8.15 & 10.32 & 16.51 \\
\hline Total: & 19.0 & 16.5 & 37.1 & 38.0 & 62.7 & 45.3 & 66.1 & 63.8 & 105.1 & 111.5 & 53.3 & 60.0 & 77.7 & 97.4 & 152.9 \\
\hline
\end{tabular}


shown ability to autolyse and to increase peptidase activity in a cheese-like medium (Rodríguez et al, 1996a). Elevated levels of amino acids at the beginning of the ripening period in cheese correspond with earlier lysis of starter bacteria (Birkeland et al, 1992; Wilkinson et al, 1994; Christensen et al, 1995).

Although the concentrations of free amino acids increased with the age of the cheese, the relative proportion of each amino acid remained essentially constant. Amino acids in higher proportion in all cheeses were Glu (16\%), Leu (14\%), Val (12\%) and Ser $(9 \%)$, and contributed about $50 \%$ to the total free amino acids. Main differences between batches were due to variations in proline and lysine proportion. The total content of these amino acids at the end of the ripening period was particularly higher in IFPL (T1) cheeses than in FD cheeses, showing a six-fold increase in proline and four-fold in lysine (table I). Substrates including lysine and proline residues have been found to be preferably hydrolysed by the intracellular enzymic fraction of $L$ lactis subsp lactis IFPL 359 (Requena et al, 1993). These results indicate that it is possible to change the composition of free amino acids in cheeses by modifying the peptidolytic properties of starter bacteria. The use in cheesemaking of a strain that overproduces a certain peptidase activity has a similar effect (Christensen et al, 1995).

\section{Volatile components}

The volatile components identified in the cheeses are listed in table II. Figure 3 shows the chromatograms of volatile components found in the three cheese batches at 90 days

Table II. Volatile components identified in ripened reduced-fat ultrafiltered cheese by GC (tentative) and GC/MS.

Composés volatils formés dans des fromages affinés à teneur réduite en matière grasse, identifiés par GC et GC/MS.

\begin{tabular}{lllll}
\hline Peak & $R T$ & Compound & $G C$ & $G C / M S$ \\
\hline 1 & 4.1 & Diacetyl & + & \\
2 & 4.5 & Acetaldehyde & + & \\
4 & 5.5 & Acetone & + & + \\
6 & 6.8 & Ethyl acetate & + & + \\
7 & 7.3 & Methanol & + & + \\
& & 3-methyl butanal & & + \\
9 & 8.1 & Dimethyl sulphide & + & + \\
9 & 8.5 & Ethanol & + & + \\
10 & 8.6 & 2-pentanone & + & + \\
11 & 10.4 & Methyl butyrate & + & + \\
13 & 11.8 & n-propanol & + & + \\
15 & 13.5 & Ethyl butyrate & + & + \\
19 & 16.9 & Dimethyl disulphide & + & + \\
21 & 20.3 & Methyl hexanoate & + & + \\
22 & 23.2 & 2-heptanone & + & + \\
22 & 25.9 & 2-methyl butanol & & + \\
25 & 25.9 & Ethyl hexanoate & + & + \\
28 & 27.2 & 3-methyl butanol & + & + \\
30 & 29.7 & 2-heptanol & + & + \\
& 31.8 & Methyl octanoate & + & + \\
\hline
\end{tabular}



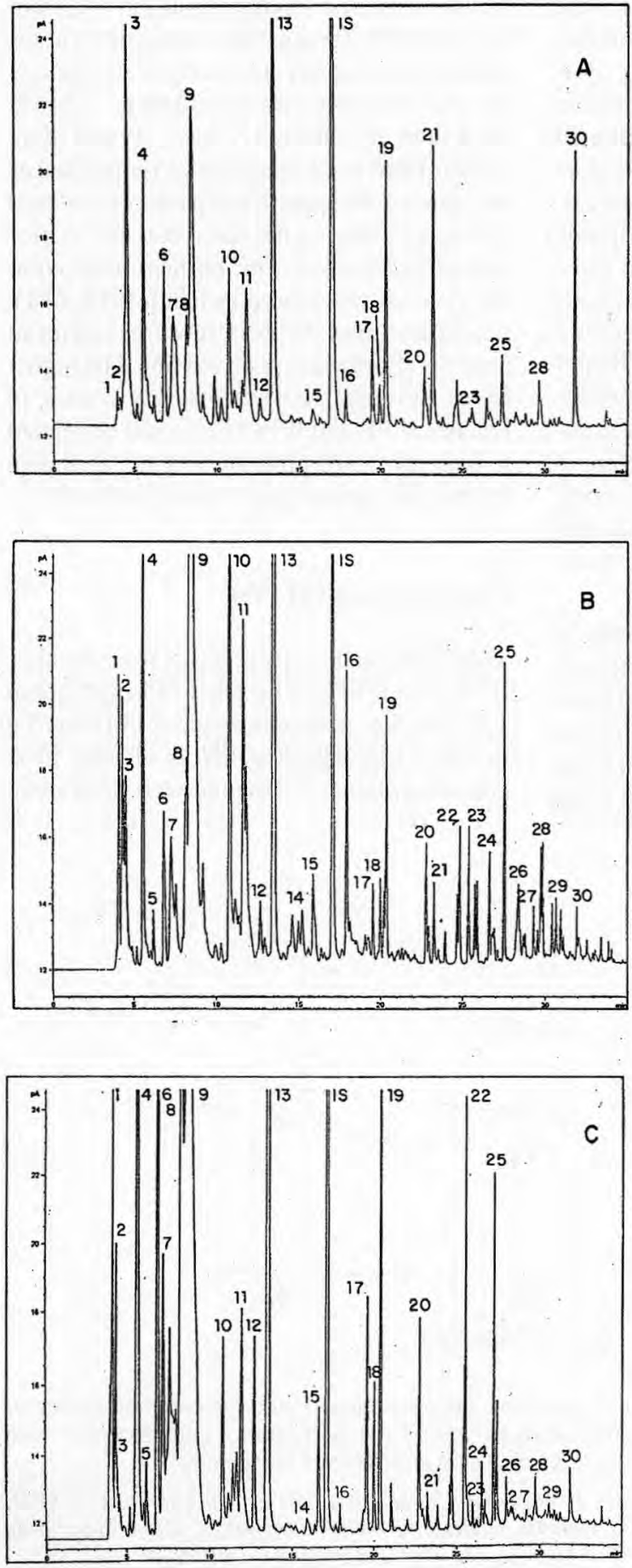

Fig 3. Chromatograms of volatile components found in cheeses prepared with the commercial starter (FD) (A), the mixed starter of local strains (IFPL) (B) and the IFPL starter supplemented with Lactococcus lactis subsp lactis $\mathrm{T} 1, \mathrm{Lac}^{-} \mathrm{Prt}^{-}$ (C), after 90 days of ripening. Peak numbers correspond to table II. Peaks 3,5 , $12,14,16,17,18,20,23$, $24,26,27,29$, not identified.

Chromatogrammes des composés volatils trouvés dans des fromages préparés avec du levain commercial (FD) (A), le levain IFPL contenant plusieurs souches $(B)$, et le même additionné d'une souche de Lactococcus lactis subsp lactis Tl ( $\mathrm{Lac}^{-} \mathrm{Prt}$ ) (C), après 90 jours d'affinage. Les pics sont numérotés comme dans le tableau II. Pics 3, 5, 12, 14, 16, 17 , $18,20,23,24,26,27,29$ : non identifiés. 
of ripening. Some of the components were identified from their mass spectra and GC retention while other were tentatively assigned by comparison with retention times of standards and published elution orders (Bosset and Gausch, 1993). Ketones, ethyl esters and methyl esters, aldehydes, alcohols, dimethyl sulphide and dimethyl disulphide were found in ripe cheeses from the three studied batches. These type of compounds have been found in other Spanish semi-hard cheeses (Martínez-Castro et al, 1991; Bosset and Gauch, 1993; Rodríguez et al, 1996a). Free fatty acids did not appear in the chromatograms since sample solutions were at $\mathrm{pH}$ 7.5. Differences among volatile components of cheeses from different batches at the same ripening time were mainly quantitative.

In order to compare results, peak areas in every chromatogram were related to that of internal standard 2-hexanone, and expressed as $\mu \mathrm{g} / \mathrm{g}$ cheese. Reproducibility of the volatile determination was estimated from variation coefficients which ranged from
4.5 to $7.8 \%$ for a standard solution and from 6.5 to $10.9 \%$ for a sample solution. Values which have been reported as satisfactory are: $3.1 \%$ (Yang and Min, 1994), 1.6-8\% (Collin et al, 1993), 7.8-18\% (Wood et al, 1994). Total volatile quantities (expressed as the sum of 30 quantified peaks) increased during ripening in the three batches as presented in figure 4 . The highest total volatile content was found in batch IFPL (T1), which also had the best score in sensorial analysis (Rodríguez et al, 1996b). The higher level of volatile components found in batches IFPL and IFPL(T1) could be related to their increased proteolysis level, as shown by the free amino acid content (table I).

\section{Free fatty acids (FFA)}

Total FFA in the ripe cheeses from batches IFPL and IFPL(T1) were $1345 \mathrm{mg} / \mathrm{kg}$ and $1324 \mathrm{mg} / \mathrm{kg}$, respectively, and $1114 \mathrm{mg} / \mathrm{kg}$ in batch FD. The low levels of total FFA can be explained by the reduced fat content

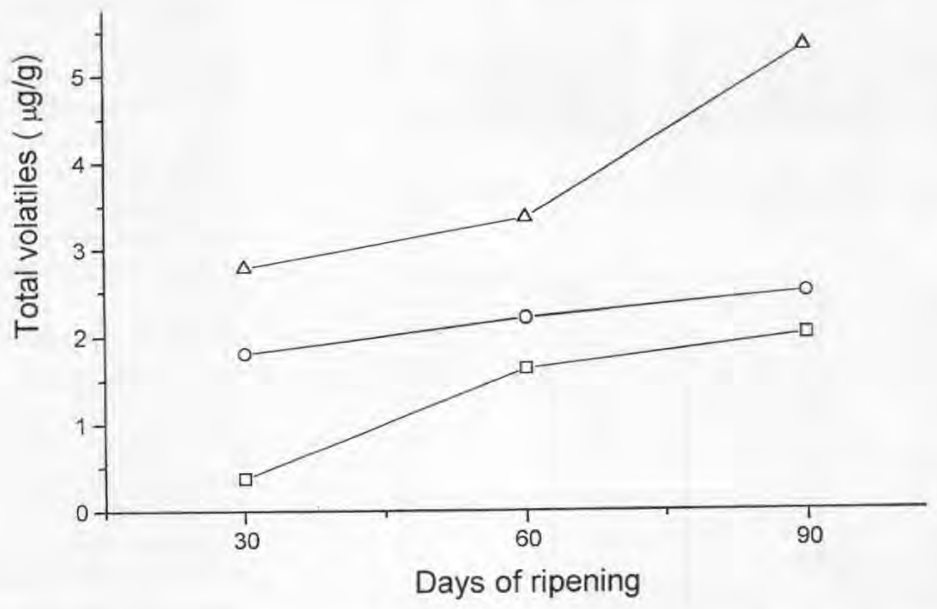

Fig 4. Total volatile components measured $(\mu \mathrm{g} / \mathrm{g})$ in cheeses prepared with the commercial starter (FD) ( $\square$ ), the mixed starter of local strains (IFPL) (O) and the IFPL starter supplemented with Lactococcus lactis subsp lactis T1, $\operatorname{Lac}^{-} \operatorname{Prt}^{-}(\Delta)$, at 30,60 and 90 days of ripening.

Composés volatils totaux $(\mu \mathrm{g} / \mathrm{g})$ dans des fromages préparés avec du levain commercial $(F D)$ (অ), le levain IFPL contenant plusieurs souches (O), et le même additionné d'une souche de Lactococcus lactis subsp lactis $\mathrm{Tl}\left(\mathrm{Lac}^{-} \mathrm{Prt}^{-}\right)(\Delta)$, après 30, 60 et 90 jours d'affinage. 
of cheeses and the scarce lipolytic activity of the starter cultures. Moderate lipolysis has been reported in semi-hard cheeses ripened without molds (De la Fuente et al, 1993), and there is commonly very little lipolysis in low-fat cheeses (Dimos, 1992; Ardö, 1994).

In conclusion, present results show that IFPL starter contributes to the acceleration of flavour development in UF-cheeses mainly through changes in both the water-soluble nitrogen fraction and the volatile components. This supports previous findings on the contribution of low molecular-mass compounds, like small peptides, amino acids, FFA or their breakdown products to the flavour of different types of cheese (Engels and Visser, 1994). The addition to the IFPL starter of $L$ lactis subsp lactis T1 $\left(\mathrm{Lac}^{-} \mathrm{Prt}^{-}\right)$greatly increased the contents of free amino acids and volatile components in the cheeses during ripening, which correlated with the best final scores on both aroma and flavour (Rodríguez et al, 1996b).

\section{ACKNOWLEDGMENTS}

The authors would like to acknowledge financial support for this study from the Comision Interministerial de Ciencia y Tecnología (Project ALI 95-0046-CO2-01). Dr J Rodríguez is the recipient of a scholarship from the Spanish Council for Scientific Research (CSIC).

\section{REFERENCES}

Ardö Y (1994) Proteolysis and flavour development in reduced fat cheese. Doctoral Thesis, Lund University, Sweden

Baankreis R (1992) The role of lactococcal peptidases in cheese ripening. Doctoral Thesis, University of Amsterdam, the Netherlands

Bech AM (1993) Characterising ripening in UF-cheese. Int Dairy J 3, 329-342

Birkeland SE, Abrahamsen RK, Langsrud T (1992) Accelerated cheese ripening: use of $\mathrm{Lac}^{-}$mutants of lactococci. J Dairy Res 59, 389-400
Bosset JO, Gauch R (1993) Comparison of the volatile flavour compounds of six European 'AOC' cheeses by using a new dynamic headspace GC-MS method. Int Dairy J 3, 359-377

Chapot-Chartier MP, Deniel C, Rousseau M, Vassal L, Gripon JC (1994) Autolysis of two strains of Lactococcus lactis during cheese ripening. Int Dairy J 4, 251-269

Christensen JE, Johnson ME, Steele JL (1995) Production of Cheddar cheese using a Lactococcus lactis ssp cremoris SK11 derivative with enhanced aminopeptidase activity. Int Dairy J 5, 367-379

Cliffe AJ, Revell D, Law BA (1989) A method for the reverse phase HPLC of peptides from Cheddar cheese. Food Chem 34, 147-160

Collin S, Osman M, Delcambre S, El-Zayat A, Dufour J (1993) Investigation of volatile flavor compounds in fresh and ripened Domiati cheeses. J Agric Food Chem 41, 1659-1663

Coulson J, Pawlett D, Wivell R (1992) Accelerated ripening of Cheddar cheese. Bull Int Dairy Fed 269, 29-35

Crow VL, Coolbear T, Gopal PK, Martley FG, McKay LL, Riepe H (1995) The role of autolysis of lactic acid bacteria in the ripening of cheese. Int Dairy $J 5$, 855-875

De la Fuente MA, Fontecha MA, Juárez M (1993) Fatty acid composition of the triglyceride and free fatty acid fractions in different cow's, ewe's and goat's milk cheeses. Z Lebensm Unters Forsch 196. $155-158$

De Koning PJ, De Boer R, Both P, Nooy PFC (1981) Comparison of proteolysis in a low-fat semi-hard type of cheese manufactured by standard and by ultrafiltration techniques. Neth Milk Dairy $J 35$, $35-46$

Dimos A (1992) A comparative study by GC/MS of the flavour volatiles produced during the maturation of full-fat and low-fat Cheddar cheese. Master Thesis, Latrobe University, Bundoora, Victoria, Australia

Drake MA, Swanson BG (1995) Reduced- and lowfat cheese technology: A review. Trends Food Sci Technol 6, 366-369

El Abboudi M, El Soda M, Pandian S, Barreau M, Trepanier G, Simard RE (1991) Peptidase activities in debittering and nondebittering strains of lactobacilli. Int Dairy J 1,55-64

El Soda M (1993) Accelerated maturation of cheese. Int Dairy J 3, 531-544

Engels WJM, Visser S (1994) Isolation and comparative characterization of components that contribute to the flavour of different types of cheese. Neth Milk Dairy J 48, 127-140

González de Llano D, Polo C, Ramos M (1995) Study of proteolysis in artisanal cheeses: high performance liquid chromatography of peptides. J Dairy Sci 78, 1018-1024 
Goudédranche H, Maubois JL, Ducruet P, Mahaut M (1980) Utilization of the new mineral UF membranes for making semi-hard cheeses. Desalination 35, 243-258

Juárez M, De la Fuente MA, Fontecha J (1992) Improved GC method for determining the individual free fatty acids in cheese using a capillary column and a PTV injector. Chromatographia 33, 351-355

Lau KY, Barbano DM, Rasmussen RR (1991) Influence of pasteurization of milk on protein breakdown in Cheddar cheese during aging. J Dairy Sci $74,727-740$

Lee BH, Laleye LC, Simard RE, Munsch MH, Holley RA (1990) Influence of homofermentative lactobacilli on the microflora and soluble nitrogen components in Cheddar cheese. J Food Sci 55, 391-397

Lemieux L, Puchades R, Simard RE (1989) Size-exclusion HPLC separation from Cheddar cheese made with added Lactobacillus strains to accelerate ripening. J Food Sci 54, 1234-1237

Lelièvre J, Lawrence RC (1988) Manufacture of cheese from milk concentrated by ultrafiltration. $J$ Dairy Res $55,465-478$

Martínez-Castro 1, Alonso L, Juárez M (1986) GC analysis of FFA and glycerides of milk fat using tetramethyl ammonium hydroxide as catalyst. Chromatographia $21,37-40$

Martínez-Castro I, Sanz J, Amigo L, Ramos M, MartínAlvarez P (1991) Volatile components of Manchego cheese. J Dairy Res 58, 239-246

Martín-Hernández MC, Alonso L, Juárez M, Fontecha J (1988) GC method for estimating FFA in cheese. Chromatographia 25, 87-90

Parra L, Requena T, Casal V, Gómez R (1996) Proteolytic activity of lactobacilli in a model goats' milk curd system. Lett Appl Microbiol 23, 375-378

Ramos M, Martínez-Castro I, Juárez M (1977) Detection of cow's milk in Manchego cheese. $J$ Dairy Sci $60,870-877$

Requena T, Mckay LL (1993) Plasmid profiles and relationship to lactose utilization/proteinase activity in a lactococcal strain isolated from semi-hard natural cheese. Milchwissenschaft 48, 264-268

Requena T, De la Fuente MA, Fernández de Palencia P, Juárez M, Peláez C (1992) Evaluation of a specific starter for the production of semi-hard goat's milk cheese. Lait $72,437-448$
Requena T, Peláez C, Fox PF (1993) Peptidase and proteinase activity of Lactococcus lactis, Lactobacillus casei and Lactobacillus plantarum. Z Lebensm Unters Forsch 196, 351-355

Resmini P, Hogenboom JA, Pazzaglia C, Pellegrino L (1993) Gli amminoacidi liberi nella caratterizzazione analitica del formaggio Grana Padano. Sci Tecn Latt-Cascaria 44, 7-19

Rodríguez J, Requena T, Martínez-Castro I, Juárez M (1996a) The accelerating effect of a Lactococcus lactis subsp lactis lactose utilization/proteinase deficient strain on proteolysis and flavour development. Z Lebensm Unters Forsch 203, 77-81

Rodríguez J, Requena T, Goudédranche H, Maubois JL, Juárez M (1996b) Accelerated ripening of reduced-fat semi-hard cheese from a mixture of cow's, goat's and ewe's ultrafiltered milk by using a $\mathrm{Lac}^{-}$ Prt strain of lactococci. Lait 76,513-522

Tan PST, van Kessel TAJM, van de Veerdonk FLM, Zuurendonk PF, Bruins AP, Konings WN (1993) Degradation and debittering of a tryptic digest from B-casein by aminopeptidase $\mathrm{N}$ from Lactococcus lactis subsp cremoris WG2. Appl Environ Microbiol $59,1430-1436$

Valero E, Miranda E, Sanz J, Martínez-Castro I (1997) Automatic thermal desorption in the GC analysis of dairy product volatiles. Chromatographia 44,59-64

Wilkinson MG, Guinee TP, O'Callaghan DM, Fox PF (1994) Autolysis and proteolysis in different strains of starter bacteria during Cheddar cheese ripening. J Dairy Res 61, 249-262

Winter A, Ek K, Anderson V (1977) Analytical electrofocusing in thin layers of polyacrylamide gels. Application Note 250 LKB, Pharmacia LKB, Uppsala, Sweden

Wood AF, Aston JW, Douglas GK (1994) A cold trap method for the collection and determination of headspace compounds from cheese. Aust J Dairy Technol 49, 42-47

Yang WT, Min DB (1994) Dynamic headspace analyses of volatile compounds of Cheddar and Swiss cheese during ripening. J Food Sci 59, 1309-1312 